\title{
Correction to: Complete genome sequence of a recombinant isolate of yambean mosaic virus from Canavalia ensiformis
}

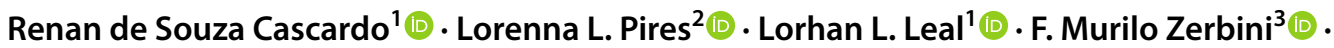 \\ Poliane Alfenas-Zerbini ${ }^{1}$ (D) . José Evando A. Beserra Jr. ${ }^{2}$ (i)
}

Published online: 3 September 2021

๑) Springer Science+Business Media, LLC, part of Springer Nature 2021

\section{Correction to: Virus Genes https://doi.org/10.1007/s11262-021-01864-7}

The original version of this article unfortunately contained incorrect supplementary material.

The supplementary material actually contains one figure and one table file but inadvertently the figure was repeated twice and table was missed to include in it.
The original article can be found online at https://doi.org/10.1007/ s11262-021-01864-7.

\section{José Evando A. Beserra Jr.}

evando@ufpi.edu.br

1 Dep. de Microbiologia/BIOAGRO, Universidade Federal de Viçosa, Viçosa, MG 36570-900, Brazil

2 Dep. de Fitotecnia, Universidade Federal do Piauí, Teresina, PI 64049-550, Brazil

3 Dep. de Fitopatologia/BIOAGRO, Universidade Federal de Viçosa, Viçosa, MG 36570-900, Brazil
The original article has been corrected.

Supplementary Information The online version contains supplementary material available at https://doi.org/10.1007/s11262-021-01868-3.

Publisher's Note Springer Nature remains neutral with regard to jurisdictional claims in published maps and institutional affiliations. 